\title{
A case of synchronous malignancy of stomach and kidney
}

\section{Senkron mide ve böbrek malignite olgusu}

\author{
Mustafa Taner BOSTANCI ${ }^{1}$, Oğuzhan EYİ ${ }^{1}$, Gülfidan ÖZTÜRK ${ }^{2}$, Ahmet SEKİ ${ }^{1}$, Fatih YALÇINKAYA ${ }^{3}$ \\ ${ }^{1}$ Dışkapı Yıldırım Beyazıd Ĕ̆̈itim ve Araştırma Hastanesi, Genel Cerrahi Klini ği, Ankara, Türkiye \\ ${ }^{2}$ Dışkapı Yıldırım Beyazıd Ĕ̆itim ve Araştırma Hastanesi, Patoloji Kliniği, Ankara, Türkiye \\ ${ }^{3}$ Dışkapı Yıldırım Beyazıd Ĕ̆itim ve Araştırma Hastanesi, Üroloji Kliniği, Ankara, Türkiye
}

\begin{abstract}
We present a case of 58- year- old- male with synchronous primary neoplasms of the stomach and kidney. The incidence of synchronous gastric cancer and renal cell carcinoma (RCC) is quite low, and concomitant surgery is rarely performed. Surgeons need to be aware of the possibility of a synchronous second primary cancer when the initial gastric cancer is diagnosed. We report this case to highlight a rare occurrence of synchronous malignancy of stomach and kidney.
\end{abstract}

Keywords: Gastric adenocarcinoma, renal cell carcinoma, synchronous malignancy

$\ddot{0} \mathbf{z}$

Senkron primer mide ve böbrek tümörü olan 58 yaşında erkek hastayı sunduk. Senkron mide kanseri ve renal hücreli karsinoma (RCC) insidansı oldukça nadirdir ve eşzamanlı cerrahi enderdir. İlk olarak mide kanseri tanısı konulduğunda cerrahların senkron ikinci primer bir kanser olasılığına dikkat etmeleri gerekmektedir. Bu olguyu nadir görülen senkron mide ve böbrek malignitesine dikkat çekmek amaciyla sunduk.

Alındığı tarih: 08.03 .2017

Kabul tarihi: 12.06 .2017

Yazışma adresi: Uzm. Dr. Mustafa Taner Bostancı, Dışkapı Yıldırım Beyazıd Eğitim ve Araştırma Hastanesi, Genel Cerrahi Klini ̌̆i, Ankara, Türkiye

Anahtar kelimeler: Gastrik adenokarsinoma, renal hücreli karsinoma, senkron malignite

e-mail: mtanerbostanci@gmail.com

\section{INTRODUCTION}

With the increasing proportion of elderly patients in the general population and regular medical checkups, the occurrence of synchronous primary cancers is becoming more frequent. The incidence of synchronous cancer in gastric cancer patients has been reported to be approximately $3 \%{ }^{(1,2)}$. The incidence of synchronous renal cell carcinoma (RCC) with gastric cancer is quite low $(0.11-0.37 \%)^{(3)}$.

Simultaneous surgical resection is the optimal treatment for synchronous malignancies, if possible.

Herein, we present our experience of performing a concomitant gastrectomy and partial nephrectomy on a patient diagnosed with synchronous gastric cancer and RCC.

\section{CASE REPORT}

During screening esophagogastroduodenoscopy of a 58 year-old male patient, a gastric mass was detected on the incisura angularis and endoscopic biopsy revealed signet ring cell carcinoma. Physical examination, past medical and family history were unremarkable. Abdominal computed tomography was obtained for preoperative staging and showed 20x15mm sized mass localized on the lower pole of the right kidney resembling renal cell carcinoma (Image 1). After urology consultation; concurrent total gastrectomy and partial nephrectomy was performed.

The patient discharged at 8th postoperative day without any complication. Histopathologic examina- 

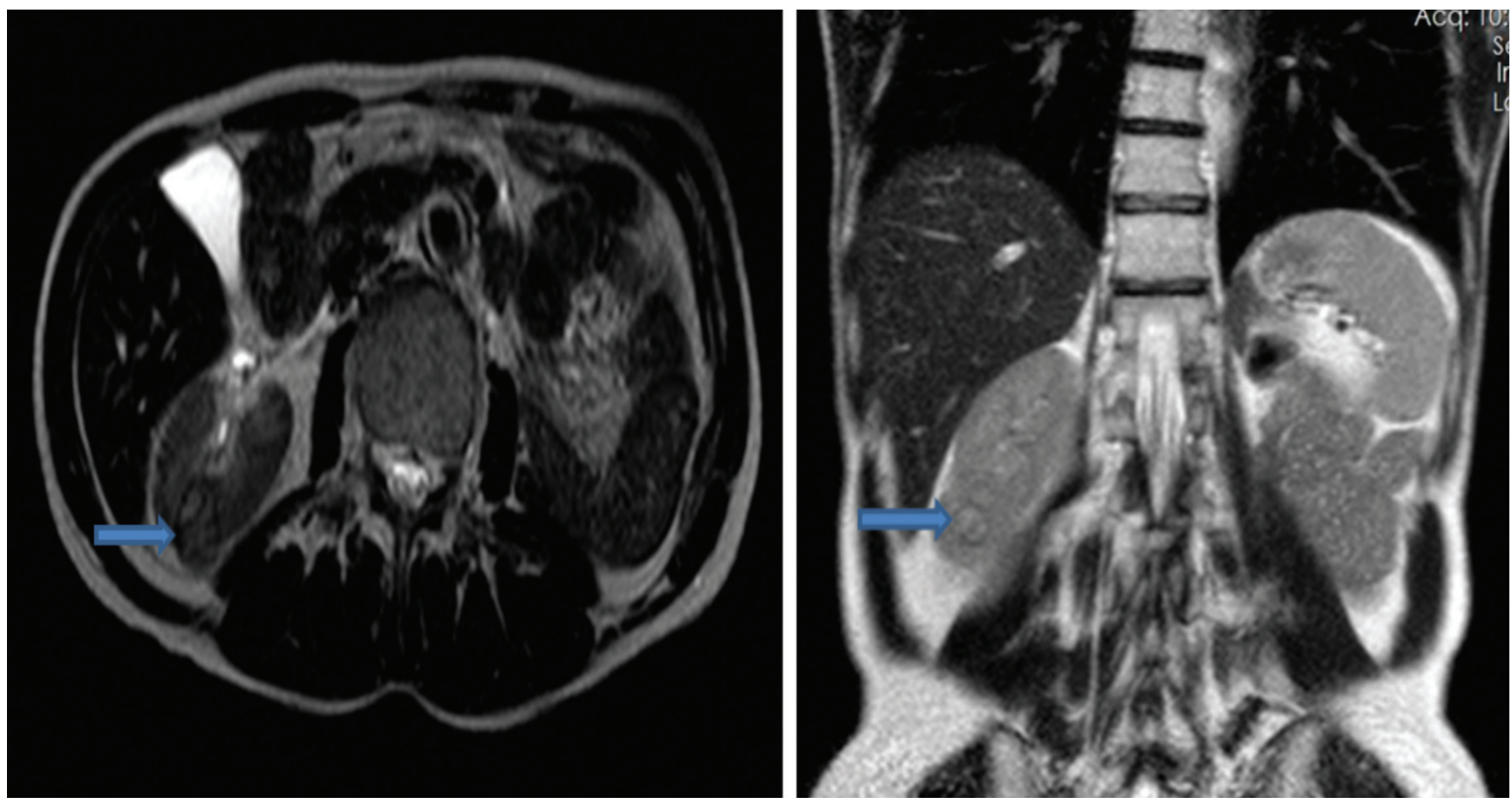

Image 1. The T2 STR images of the lesion in right kidney (arrow).

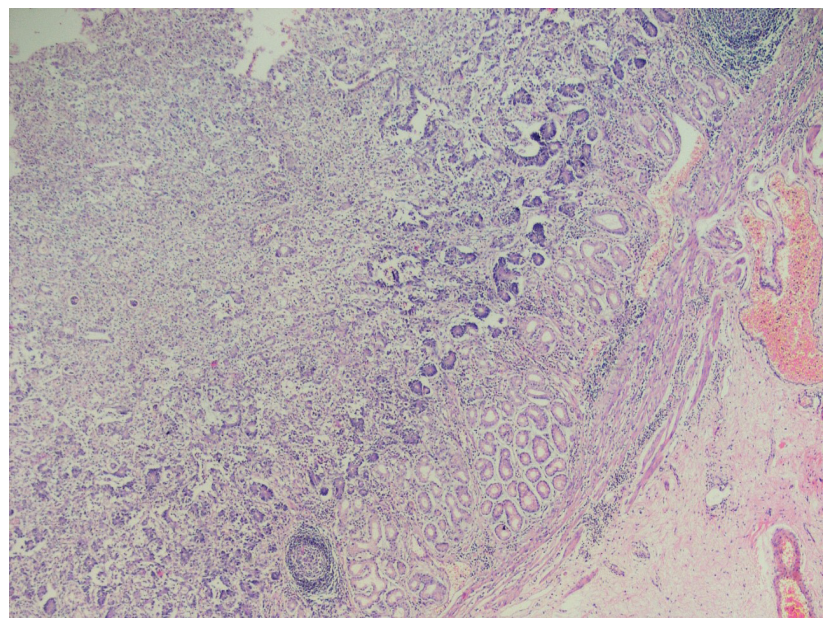

Figure 1. Destruction of normal anathomy of antral mucosa by poorly cohesive adenocarcinoma $(\mathrm{H} \& \mathrm{E} \times 40)$.

tion of gastrectomy specimen showed; $4 \times 1,5 \times 1 \mathrm{~cm}$ sized signet ring cell carcinoma, localized within the muscularis propria (Figure 1-3). Any metastatic lesion was not detected in 32 retrieved lymph nodes. The gastric carcinoma was pT2N0 and Stage 1B with regard to American Joint Committee on Cancer. Histopathologic examination of partial nephrectomy specimen showed the presence of a $3 \times 2 \times 1.5 \mathrm{~cm}$ sized and $\mathrm{T} 1$ papiller type of renal cell carcinoma with

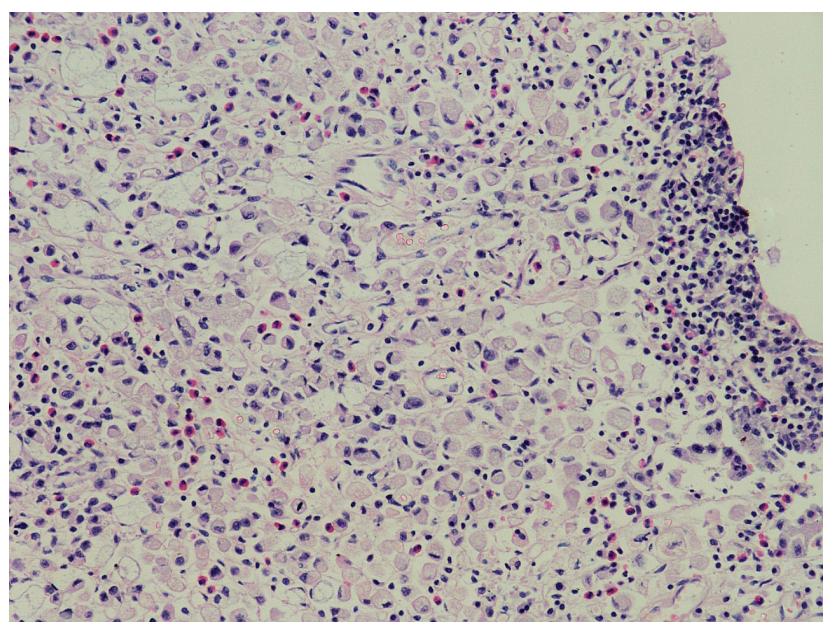

Figure 2. Signet ring cells, nucleus of the cells are pushed to periphery by intracytoplasic mucin (H\&E x400).

negative resection margins (Figures 4, and 5). Patient examined at $6^{\text {th }}$ postoperative month and there was no complication or recurrence.

\section{DISCUSSION}

Second neoplasms are classified as "synchronous", and defined as occurrence of the index tumour and second malignancy within six months of each other ${ }^{(4)}$. 


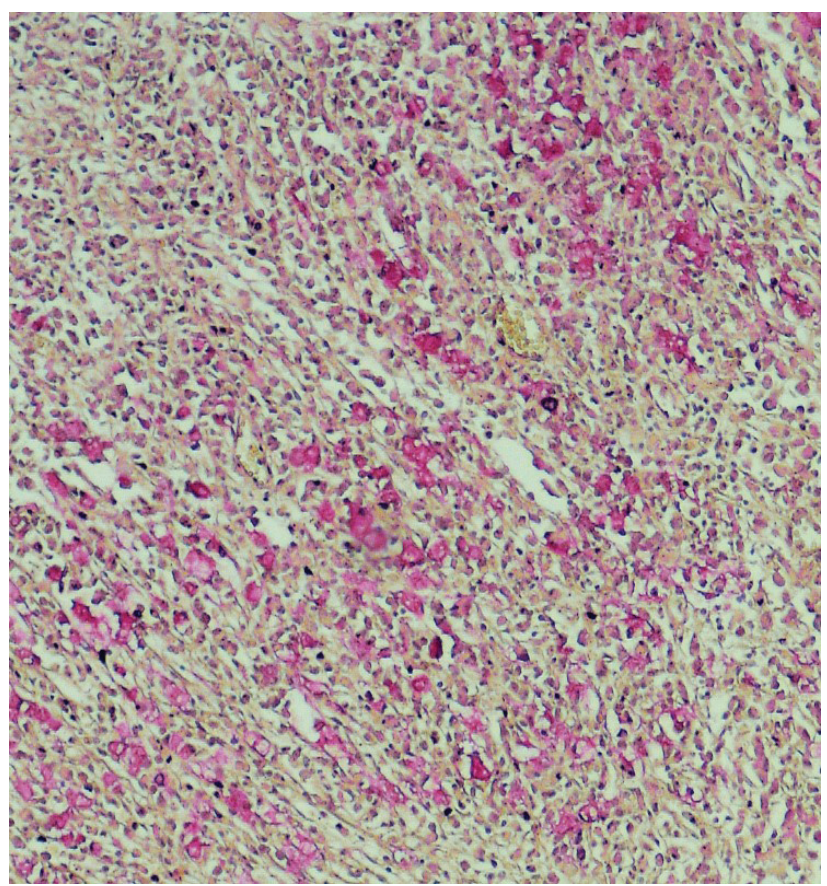

Figure 3. Intracytoplasmic mucin is demonstrated by mucicarmin $x 400$

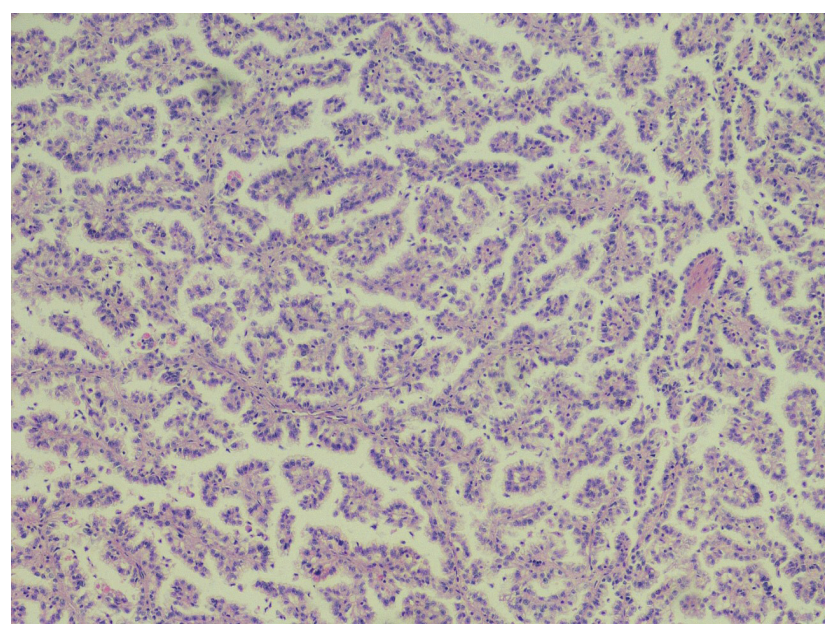

Figure 4. Papillary renal cell carcinoma, papillary folds are lined by single layered cuboidal epithelium (H\&E x 100).

A study by Lee et al. ${ }^{(5)}$ showed that the incidence of synchronous cancer in gastric cancer patients was $3.4 \%$, with the most common synchronous sites being colorectal cancer $(37.2 \%)$, followed by lung cancer $(18.6 \%)$, esophageal cancer $(16.8 \%)$, liver cancer $(9.7 \%)$, and kidney cancer $(4.4 \%)$.

Gastrointestinal symptoms are the most common clinical manifestations in patients with synchronous cancer of the kidney and stomach. Most renal tumors are found incidentally via imaging studies ${ }^{(1)}$.

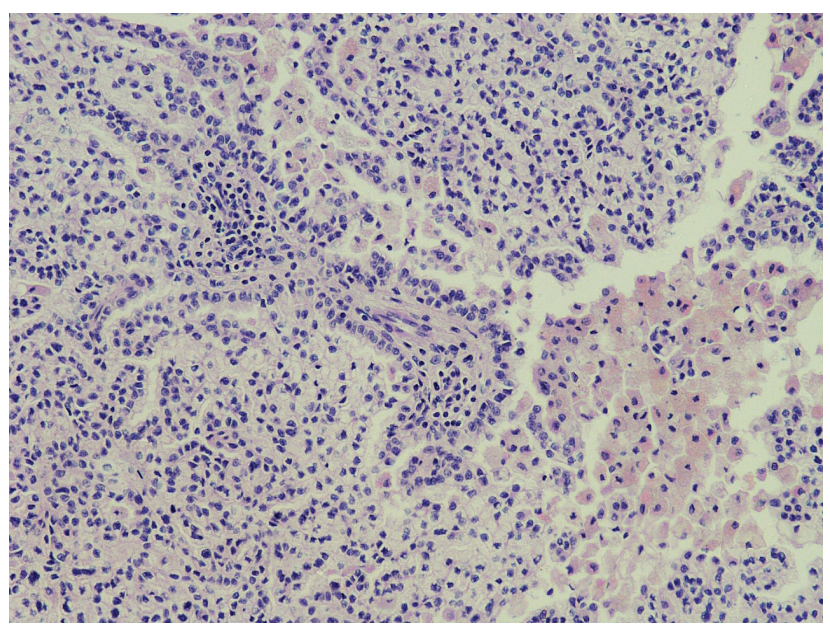

Figure 5. Papillary renal cell carcinoma, papillary features with numerous foamy macrophages (H\&E x200).

One of the most important factors when deciding the best treatment modality for multiple primary cancer patients is the stage of the synchronous cancers (1,6).

Most patients who have resectable synchronous tumors have both tumors operated on at the same time which does not lead to increased postoperative mortality ${ }^{(2)}$.

A study by Ikeda et al. ${ }^{(7)}$ showed that the respective 10 -year survival rates are $40.1 \%$ and $69.3 \%$ for gastric cancer patients with and without a second primary cancer. This difference between the two groups is statistically significant.

In our patient, no tumor recurrence was noted at 6th month follow-up examination, although more time is required to further elucidate these results.

For multiple primary cancers, including head and neck, gastric, and colon cancer, it is hypothesized that chemical and physical stimuli affect the gastrointestinal tract from the oral cavity to the upper and lower gastrointestinal system, leading to field carcinogenesis ${ }^{(8)}$. But, the molecular basis for the association of synchronous double cancers is not completely understood ${ }^{(9)}$.

The incidence of synchronous gastric cancer and RCC is quite low, and concomitant surgery is rare. Surgeons need to be aware of the possibility of a synchronous second primary cancer when the initial gastric cancer is diagnosed. We believed that radical 
surgery plays a major role in the treatment and a concomitant gastrectomy and radical nephrectomy can be safely performed in selected patients without the development of major complications.

\section{REFERENCES}

1. Bae JS, Lee JH, Ryu KW, Kim YW, Bae JM. Characteristics of synchronous cancers in gastric cancer patients. Cancer Res Treat. 2006;38:25-9.

https://doi.org/10.4143/crt.2006.38.1.25

2. Eom BW, Lee HJ, Yoo MW, Cho JJ, Kim WH, Yang HK, et al. Synchronous and metachronous cancers in patients with gastric cancer. J Surg Oncol. 2008;98:106-10. https://doi.org/10.1002/jso.21027

3. Kung-Ning Hu, Wei-Hong Lai, Po-Tsang Tseng, Wen-Ching Wang, Kun-Hung Shen. Synchronous primary gastric cancer and renal cell carcinoma: A case report and literatures review. Urological Science. 2012;23:28-30.

https://doi.org/10.1016/j.urols.2011.12.007
4. Sarkar S, Kundu AK, Chakrabarti S. Lungs: Victim of Synchronous Double Malignancies. J Assoc Physicians India. 2007;55:235-7.

5. Lee JH, Bae JS, Ryu KW, Lee JS, Park SR, Kim CG, et al. Gastric cancer patients at high-risk of having synchronous cancer. World J Gastroenterol. 2006;12:2588-92. https://doi.org/10.3748/wjg.v12.i16.2588

6. Oh SJ, Bae DS, Suh BJ. Synchronous triple primary cancers occurring in the stomach, kidney, and thyroid. Ann Surg Treat Res. 2015;88(6):345-8. https://doi.org/10.4174/astr.2015.88.6.345

7. Ikeda Y, Saku M, Kawanaka H, Nonaka M, Yoshida K. Features of second primary cancer in patients with gastric cancer. Oncology. 2003;65:113e7.

8. Hamada M, Naomoto Y, Fujiwara T, Kamikawa Y, Tanaka N. Suppressed apoptotic induction in esophageal squamous cell carcinomas expressing extensive p53 protein. Jpn J Clin Oncol. 1996;26:398-404.

https://doi.org/10.1093/oxfordjournals.jjco.a023255

9. Cheng HY, Chu $\mathrm{CH}$, Chang WH, Hsu TC, Lin SC, Liu CC, et al. Clinical analysis of multiple primary malignancies in the digestive system: a hospital-based study. World J Gastroenterol. 2005;11:4215e9. 